\title{
IDENTIFIKASI JENIS PAKAN LEBAH MADU HUTAN (Apisdorsata) DI HUTAN LINDUNG KESATUAN PENGELOLAAN HUTAN LINDUNG (KPHL) AMPANG KECAMATAN EMPANG KABUPATEN SUMBAWA TAHUN 2020
}

\author{
Oleh: \\ Arifin, Irna Ningsi Amalia Rachman \\ Program Studi Kehutanan Universitas Pendidikan Mandalika \\ Email: arifinempang@gmail.com
}

Abstrak

\begin{abstract}
Penelitian ini di laksanakan di Kawasan Hutan Lindung KPHL Ampang Yang berlokasi di Desa Jotang Beru dengan tujuan : mengidentifikasi Jenis vegetasi tingkat pohon dan tumbuhan bawah yang berpotensi sebagai pakan lebah madu hutan. Metode yang di gunakan dalam penelitian ini dalam teknik pengambilan data adalah dengan mengetahui dan mengidentifikasi jenis pakan lebah hutan yaitu berupa vegetasi jenis pohon dan tumbuhan bawah maka dilakukan dengan cara survey yaitu turun langsung ke hutan dan mendata jenis-jenis pakan lebah yang biasa disukainya. Kemudian untuk menganalisis data Jenis-jenis vegetasi yang di peroleh di tabulasi, dan di diskripsikan baik itu untuk vegetasi pohon maupun tumbuhan bawah. Berdasarkan hasil penelitian dan analisis yang telah dilakukan, maka dapat disimpulkan sebagai berikut Identifikasi jenis Vegetasi yang di jumpai pada Lokasi Hutan Lindung Kesatuan Pengelolaan Hutan (KPHL) Ampang ditemukan sebanyak 27 jenis vegetasi terdiri dari 11 Jenis adalah pada tingkat tiang dan 16 jenis pada tingkat tumbuhan bawah, yang termasuk jenis pakan lebah madu hutan (Apisdorsata). Di harapkan dari hasil penelitian ini ada upaya tindak lanjut dari pemerintah perlu upaya pelestarian jenis tanaman sebagai jenis pakan lebah madu hutan khususnya di Kawasan Hutan Kesatuan Pengelolaan Hutan Lindung (KPHL) Ampang
\end{abstract}

Kata Kunci : Tingkat pohon, vegetasi dan tumbuhan bawah.

\section{PENDAHULUAN}

Indonesia merupakan salah satu negara tropis yang memiliki kekayaan alam melimpah berupa flora dan fauna. Salah satu fauna yang bermanfaat bagimanusia adalah lebah madu.Hasil yang dapat diperoleh dari beternak lebah madu adalah madu, polen, royal jeli, propolis, dan lilin lebah.Produk yang dihasilkan dapat memberikan keuntungan ekonomis bagi peternaknya, dengan memberikan lapangan pekerjaan dan menambah penghasilan.Salah satu faktor yang berpengaruh dalam keberhasilan budidaya lebah madu adalah tersedianya pakan lebah.Sumber pakan lebah madu adalah tanaman yang meliputi tanaman buah, tanaman sayuran, tanaman hias, tanaman pangan, tanaman hutan, dan tanaman perkebunan (Rusfidra, 2006).

\section{METODOLOGI PENELITIAN}

Metode yang di gunakan dalam penelitian ini dalam teknik pengambilan data adalah dengan mengetahui dan mengidentifikasi jenis pakan lebah hutan yaitu berupa vegetasi jenis pohon dan tumbuhan bawah maka dilakukan dengan cara survey yaitu turun langsung ke hutan dan mendata jenis-jenis pakan lebah yang biasa disukainya

\section{a. Alat dan Bahan}

Bahan dan alat yang digunakan dalam penelitian adalah tali rafiah, pita ukur, kompas, tally sheet, alat tulis, kalkulator, pelindung dari lebah, alat topografi, kantong plastik, kertas label, papan jalan dan kamera

\section{b. Rancangan Percobaan}

Penelitian dilaksanakan di hutan lindung kesatuan pengelolaan hutan lindung (KPHL) Ampang Kecamatan Empang Kabupaten Sumbawa. Rencana waktu penelitian dilakukan 
selama 1 bulan yaitu dari tanggal 1 Januari sampai 30 Februari 2020. Desa Empang, ini merupakan salah satu daerah yang berbatasan dengan kawasan hutan dimana banyak terdapat lebah madu hutan (Apis Dorsata).

\section{c. Cara Kerja}

Dalam penelitian ini, ada dua sumber data yang digunakan yaitu:

1. Data primer merupakan data yang dikumpulkan secara langsung oleh peneliti dari sumbernya, diamati, di ukur dan di catat untuk pertama kalinya dengan menggunakan instrument pengamatan seperti pencatatan dengan alat tulis(Arikunto, 1997). Dalam penelitian ini, peneliti melakukan pengamatan dan pencatatan data secara sistematik

2. Data sekunder adalah data yang bukan diusahkan sendiri pengumpulannya oleh peneliti, namun diperoleh dari instansi terkait atau sumber lainnya (Marzuki, 1989).

\section{d. Analsis Data}

Jenis-jenis vegetasi yang di peroleh di tabulasi, dan di diskripsikan baik itu untuk vegetasi pohon maupun tumbuhan bawah.

\section{HASIL dan PEMBAHASAN}

\section{a.Hasil}

Jenis-Jenis Vegetasi Pakan Lebah

Madu Hutan (Apisdorsata)

Tabel 1. pohon sebagai pakan lebah madu hutan

\begin{tabular}{lll}
\hline No & Nama & Nama Latin \\
\hline 1. & Binong/boan & Tetrameles nudiflora \\
2. & Kesambi & Schleihera oleosa \\
3. & Jati & Tectona grandis \\
4. & Lamtoro & Leucaena leucocephala \\
5. & Asam jawa & Tamarindus indica \\
6. & Gamal & Gliricidia sepium \\
7. & Bidara & Ziziphus mauritina \\
8. & Randu & Ceiba pentandra \\
9. & Jati putih & Gmelina arborea \\
10. & Mahoni & Swietenia mahagoni \\
11. & Kayu jawa & Lannea coromandelica \\
\hline
\end{tabular}

Sumber : Hasil Pengolahan data 2020

Berdasarkan Tabel 1 di atas dapat dilihat bahwa jenis vegetasi pakan lebah madu hutan terdapat 11 jenis sebagai pakan lebah madu hutan Tabel 2. Tumbuhan Bawah sebagai
Pakan Lebah Madu Hutan

\begin{tabular}{|c|c|c|}
\hline No & Nama & Nama Latin \\
\hline 1. & Kopasanda & Chromolaena odorata \\
\hline 2. & Pacar Kuku & Lawsonia inermis \\
\hline 3. & Sambiloto & Andrographis paniculata \\
\hline 4 & $\begin{array}{l}\text { Paliasa/ } \\
\text { katimaha }\end{array}$ & Klenhovia hospita linn \\
\hline 5. & Awar-Awar & Ficus septica \\
\hline 6. & Bayam & Amaranthus spinosus \\
\hline 7. & Duri & Passiflora foetida \\
\hline 8. & Rambusa & Ecliptaprostrate \\
\hline 9. & Urang- & Phyllanthus urinaria $L$. \\
\hline 10. & $\begin{array}{l}\text { aring } \\
\text { Meniran }\end{array}$ & Peperomia pellucida \\
\hline 11 & Ketumpang & Stachytarpheta \\
\hline 12. & air/ sirih & jamaicensis \\
\hline 13. & cina & Justicia gendarussa \\
\hline 14. & pacut kuda & Memordica charantia $L$. \\
\hline 15. & Gandarusa & Dioscore hispida \\
\hline \multirow[t]{5}{*}{16.} & Pare hutan & Mimosa pudica \\
\hline & Gadung & Jatropha gossypiifolia \\
\hline & Putri malu & \\
\hline & Jarak & \\
\hline & merah & \\
\hline
\end{tabular}

Sumber :Hasil Pengolahan Data 2020.

Berdasarkan tabel 2 di atas dapat dilihat bahwa jenis tumbuhan bawah sebagai pakan lebah madu hutan terdapat 16 jenis pakan lebah madu hutan.

\section{b. Pembahasan}

\section{Letak dan Luas}

Berdasarkan informasi yang diperoleh dari kantor Kesatuan Pengelolaan Hutan Lindung (KPHL) Ampang, bahwa luas dari kawasan hutan didusun Tero $\pm 1200 \mathrm{Ha}$.

Adapun batas-batas desa adalah :

$\begin{array}{lll}\text { - Sebelah Barat } & \text { : Jotang Beru } \\ \text { - } & \text { Sebelah Timur } & \text { : Tero } \\ \text { - } & \text { Sebelah Selatan } & \text { : Pamanto } \\ \text { - } & \text { Sebalah Utara } & \text { : Mangkung }\end{array}$

\section{Topografi}

Wilayah Kecamatan Empang memiliki topografi yang beraneka ragam. Hal ini dapat dilihat dari ketinggian yang berbeda-beda di atas permukaan laut (dpl) yaitu $15 \mathrm{~m} \mathrm{dpl}$ pada daerah pantai sampai dengan $300 \mathrm{~m}$ dpl pada daerah pengunungan. Khusus untuk kawasan hutan Lindung Kesatuan Pengelolaan Hutan Lindung (KPHL) Ampang yang terletak di wilayah Desa Jotang Beru, Kecamatan Empang termasuk kriteria daerah bergelombang kemiringan $15-40 \%$

\section{Geologi}

Berdasarkan peta geologi Kecematan Empang keadaan geologi di Kabupaten Sumbawa, Nusa Tenggara Barat skala 1 : 100.000, Kabupaten Sumbawa terdari formasi batuan. Batuan Gunung api, terdiri dari batuan muda, dan tua dan lebih tua. 


\section{Jenis Tanah}

Jenis tanah yang terdapat di kawasan hutan Lindung Kesatuan Pengelolaan Hutan Lindung (KPHL) Ampang Desa Jotang Beru, Kecamatan Empang adalah tanah dengan jenis Litosol pada umumnya mempunyai tekstur sedang sampai agak kasar, yaitu lempung sampai lempung berpasir.

\section{Iklim}

Berdasarkan Data Sekunder, kawasan hutan Lindung Kesatuan Pengelolaan Hutan Lindung (KPHL) Ampang yang terletak di Desa Jotang Beru, Kecamatan Empang termasuk iklim tropis. Karakteristik iklim tropis, dengan suhu udara sekitar $20^{\circ} \mathrm{C}-30^{\circ} \mathrm{C}$ dan ratarata curah hujan $1.038,73 \mathrm{~mm} /$ tahun.

\section{Jenis Pohon}

1. Binong/boan (Tetrameles nudiflora)

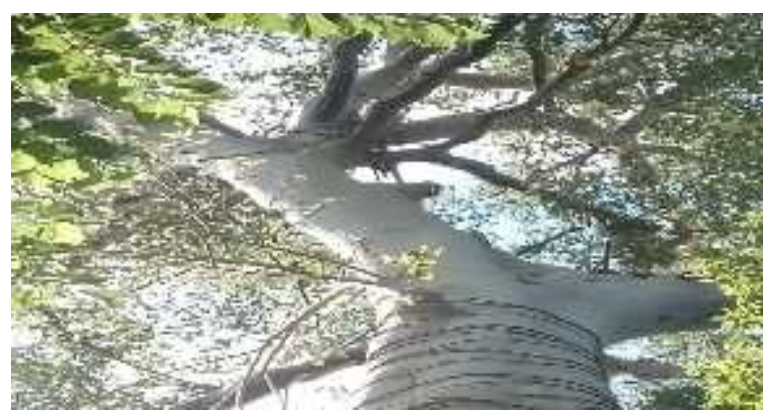

Pohon binong ciri has pada akar tambinya yang dapat menjalar di permukaan tanah dan bebatuan. Selain itu sosok batangnya yang tinggi mampu mencapai 50 meter. Batang bagian bawah tidak bercabang hingga ketinggian sekitar 30-an meter. Kulit batang halus, diameter batang juga cukup besar mampu mencapai 2 meter. Daun pohon binong berbentuk hati berwarna hijau dengam tepi daun bergerigi dengan panjang 10-26 $\mathrm{cm}$ dan lebar 9-20 cm. Bunganya tersusun dalam malai yang terdiri atas bunga jantan dan bunga betina, buah binong lonjong atau bulat telur. (Mujatahid, A. 2005)

\section{Klasifikasi ilmiah:}

$\begin{array}{lll}\text { Kingdom } & : & \text { Plantae } \\ \text { Divisio } & : & \text { Magnoliophyta } \\ \text { Classis } & : & \text { Magnoliopsida } \\ \text { Ordo } & : & \text { Violales } \\ \text { Familia } & : & \text { Datiscaceae } \\ \text { Genus } & : & \text { Tetrameles } \\ \text { Species } & : & \text { Tetrameles nudiflora } R . B r .\end{array}$

2. Kesambi (Schleihera oleosa)

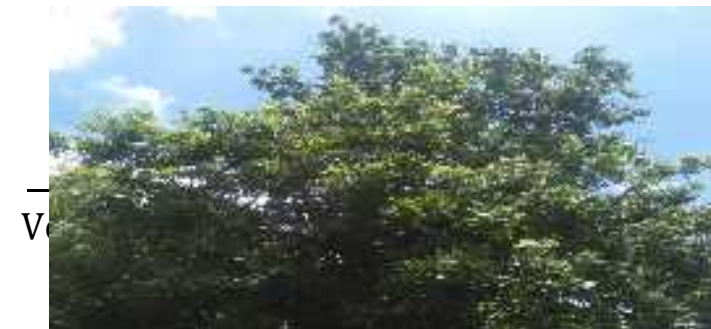

Adalah nama sejenis pohon daerah kering, kerabat rambutan dari suku Sapindaceae. Pohon kesambi tumbuh alami di lembah Himalaya, Srilangka dan Indonesia. Di Indonesia kesambi tumbuh baik di Jawa, Bali, Nusa Tenggara, Sulawesi, Maluku, Pulau Seram dan Pulau Kai (Heyne,1987).

\section{Ciri-cirinya:}

Menurut Siswanto (2010) yaitu:

1. Pohon kesambi dapat mencapai tinggi hingga $40 \mathrm{~m}$, dengan diameter hingga $2 \mathrm{~m}$. Biasanya batang pohon kesambi selalu bengkok dan bermata kayu serta berbanir, kulitnya halus, berwarna abu-abu.

2. Batangnya silindris berkerut dan tipis, berbulu pendek berwarna kuning kemerahan ketika mudah dengan kelenjar tertentu, hitam, kemudian coklat kuningan seperti abu.Daunnya bersirip genap, anak daun terakhir seringkali seperti ujung anak daun.

3. Bentuk daunnya lanset, berseling, panjang 11-25 cm, lebar 2-6 cm, tepi rata, ujung lancip,pertulangan menyirip, tangkai bulat panjang $+1 \mathrm{~cm}$ dan berwarna hijau.

4. Bunga kesambi bunga majemuk berbentuk tandam di ketiak daun atau ujung batang, kelopak 4-6 lembar, bersatu di pangkal, berduri, hijau dan warna mahkotanya putih.

5. Buah dan biji berbentuk bulat dengan diameter biji $6-10 \mathrm{~cm}$ buah terdiri atas 1-2 biji dikelilingi oleh kulit berwarna cokelat kehitaman.

\author{
Klasifikasi ilmiah: \\ Kingdom : Plantae \\ Divisi : Magnolpophyta
}




$\begin{array}{lll}\text { Classis } & : & \text { Magnoliopsida } \\ \text { Ordo } & : & \text { Sapindales } \\ \text { Familia } & : & \text { Sapindaceae } \\ \text { Genus } & : & \text { Schleichera } \\ \text { Species } & : & \text { Schleichera Oleosa MERR }\end{array}$

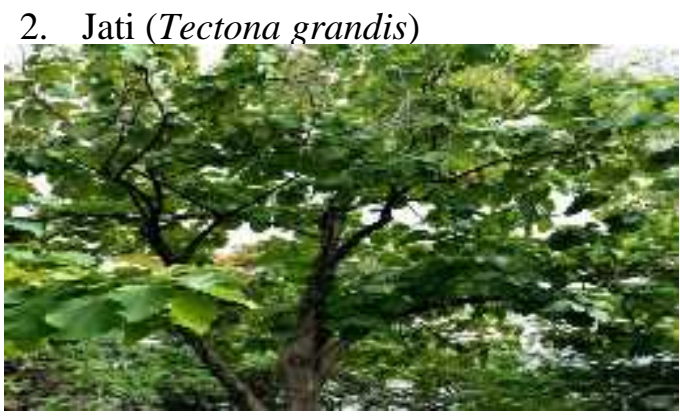

Jati adalah sejenis pohon penghasil kayu bermutu tinggi. Pohon besar, berbatang lurus, dapat tumbuh mencapai tinggi 30-40 meter dan dengan diameter sekitar $200 \mathrm{~cm}$. Dalam bahasa inggris pohon jati dikenal oleh dunia dengan sebutan teak yang diambil dari kata thekku dalam bahasa Malayam (Suryana, 2001).

\section{Klasifikasi ilmiah:}

$\begin{array}{lcl}\text { Kingdom } & : & \text { Plantae } \\ \text { Divisio } & : & \text { Magnoliophyta } \\ \text { Classis } & : & \text { Magnoliopsida } \\ \text { Ordo } & : & \text { Lamiales } \\ \text { Familia } & : & \text { Lamiaceae } \\ \text { Genus } & : & \text { Tectona } \\ \text { Species } & : & \text { T. grandis }\end{array}$

\section{Lamtoro (Leucaena leucocephala)}

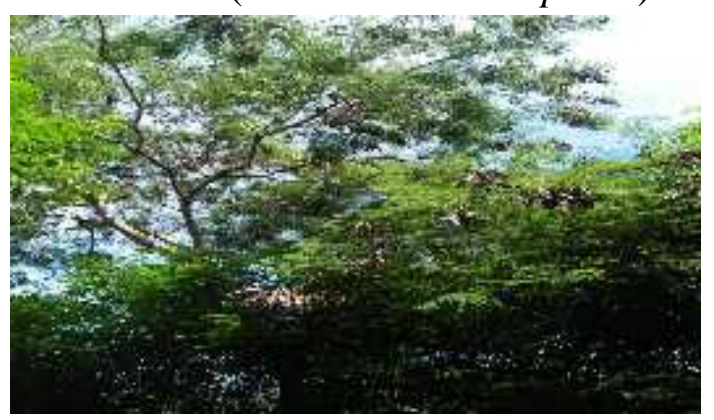

Lamtoro sejenis perdu dari suku Fabaceae (Leguminosae, polong-polongan), yang kerap digunakan dalam penghijauan lahan atau pencegahan erosi. Berasal dari Amerika tropis, tumbuhan ini sudah ratusan tahun di perkenalkan ke Jawa untuk kepentingan pertanian dan kehutanan, dan kemudian menyebar pula ke pulau-pulau yang lain di Indonesia. Tanaman ini di
Malaysia dinamai petai belalang (Kustiawan,2001).

\section{Ciri-cirinya :}

Menurut Siswanto 2010:

1. Pohon atau perdu memiliki tinggi hingga $20 \mathrm{~m}$, meski kebanyakan hanya sekitar 2-10 m. Percabangannya rendah dan banyak, dengan pepagan berwarna kecokelatan atau keabu-abuan, berbintilbintil dan berlentisel.

2. Ranting-rantingnya berbentuk bulat torak, dengan ujung yang berambut rapat.

3. Daunnya majemuk dan berbentuk menyirip rangkap, siripnya berjumlah 310 pasang, kebanyakan dengan kelenjar pada poros daun tepat sebelum pangkal sirip terbawah, daun penumpu kecil, bentuk segitiga.

4. Anak daun tiap sirip 5-20 pasang, berhadapan, bentuk garis memanjang 6$16(-21) \mathrm{mm} \times 1-2(-5) \mathrm{mm}$, dengan ujung rancing dan pangkal miring (tidak sama), permukaannya berambut halus dan tepinya berjumbai.

5. Bunganya majemuk berupa bongkol bertangkai panjang berkumpul dalam malai berisi 2-6 bongkol, tiap-tiap bongkol tersusun dari 100-180 kuntum bunga, membentuk bola berwarna putih atau kekuningan berdiameter 12-21 $\mathrm{mm}$, di atas tangkai sepanjang $2-5 \mathrm{~cm}$. Bunga kecil-kecil, berbilangan 5, tabung kelopak bentuk lonceng bergigi pendek, lk $3 \mathrm{~mm}$, mahkota berbentuk solet $1 \mathrm{k} 5$ $\mathrm{mm}$, lepas-lepas, benang sari 10 helai, $\mathrm{lk}$ $1 \mathrm{~cm}$, lepas-lepas

6. Buahnya polong berbentuk pita lurus, pipih dan tipis, $14-26 \mathrm{~cm} \times 2 \mathrm{~cm}$, dengan sekat-sekat di antara biji, hijau dan akhirnya cokelat kehijauan atau coklat tua apa bila kering jika masak, memecah sendiri sepanjang kampuhnya. Buah lamtoro mengandung 15-30 biji yang terletak melintang dalam polongan, berbentuk bulat telur sungsang atau bundar telur terbaik, dengan warna coklat tua mengkilap yang berukuran 6 $10 \mathrm{~mm} \times 3-4,5 \mathrm{~mm}$. Bijinya mirip petai, namun berukuran lebih kecil dan berpenampang lebih kecil.

\section{Klasifikasi ilmiah:}

Kingdom : Plantae 


$\begin{array}{lll}\text { Divisio } & : & \text { Magnoliophyta } \\ \text { Classis } & : & \text { Magnoliopsida } \\ \text { Ordo } & : & \text { Fabales } \\ \text { Familia } & : & \text { Fabaceae } \\ \text { Genus } & : & \text { Leucaena } \\ \text { Spesies } & : & \text { Leucaena leucocephala }\end{array}$

4. Asam Jawa (Tamarindus indica)

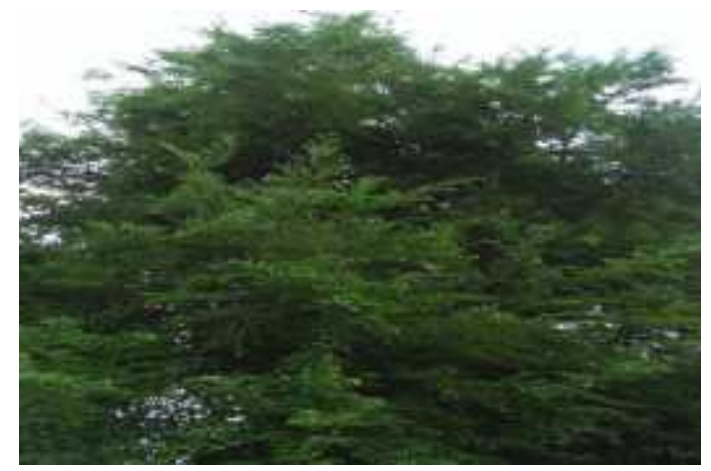

Asam jawa, asam atau asem adalah sejenis buah yang masam rasanya, biasa digunakan sebagai campuran bumbu dalam banyak masakan Indonesia sebagai perasa atau penambah rasa asam atau kadang-kadang pada kuah pempek. Asam juga digunakan untuk campuran jamu tradisional yang dijual oleh penjual jamu keliling, biasanya ibu-ibu yang menggendong bakul dengan botol berisi aneka jamu (jamu gendong). Asam jawa dihasilkan oleh pohon dengan nama ilmiah Tamarindus indicayang termasuk suku Fabaceae (Leguminosae). Spesies ini adalah satu-satunya anggota marga Tamarindus.Pohon asam berperawakan besar, selalu hijau (tidak mengalami masa gugur daun), tinhggi sampai $30 \mathrm{~m}$ dan diameter batang di pangkal hingga $2 \mathrm{~m}$. Kulit batang berwarna coklat ke abuabuan, kasar dan memecah, beralur-alur vertical.Tajuknya rindang dan lebat berdaun, melebar dan membulat.(Nagy, Shaw 1980).

Daun majemuk menyirip genap,panjang 5-13 cm, terletak berseling, dengan daun penumpu seperti pita meruncing, merah jambu keputihan. Anak daun lonjong menyempit,8-16 pasang, masing-masing berukuran 0,5$1 \times 1-3,5 \mathrm{~cm}$, bertepi rata, pangkalnya miring dan membundar, ujung membundar sampai sedikit berlekuk.

Bunga tersusun dalam tandan renggang, di ketiak daun atau di ujung ranting, sampai $16 \mathrm{~cm}$ panjangnya. Bunga kupu-kupu dengan kelopak 4 buah dan daun mahkota 5 buah,berbau harum, mahkota kuning keputihan dengan uraturat merah coklat,sampai1,5 cm.Buah polong yang menggelembung, hampir silindris,bengkok atau lurus, berbiji sampai 10 butir, sering dengan penyempitan di atara dua biji, kulit buah (eksokarp) mengeras berwarna kecoklatan atau kelabu bersisik, dengan urat-urat yang mengeras dan liat serupa benang, daging buah (mesokarp) putih kehijauan ketika muda, menjadi merah kecoklatan sampai kehitaman ketika sangat masak, asam manis dan melengket, biji coklat kehitaman, mengkilap dan keras, agak persegi (Nagy, Shaw 1980).

\section{Klasifikasi ilmiah:}

$\begin{array}{lll}\text { Kingdom } & : & \text { Plantae } \\ \text { Divisio } & : & \text { Magnoliophyta } \\ \text { Classis } & : & \text { Magnoliopsida } \\ \text { Ordo } & : & \text { Fabales } \\ \text { Familia } & : & \text { Fabaceae } \\ \text { Genus } & : & \text { Tamarindus } \\ \text { Spesies } & : & \text { T.indica }\end{array}$

5. Gamal ( Gliricidia sepium )

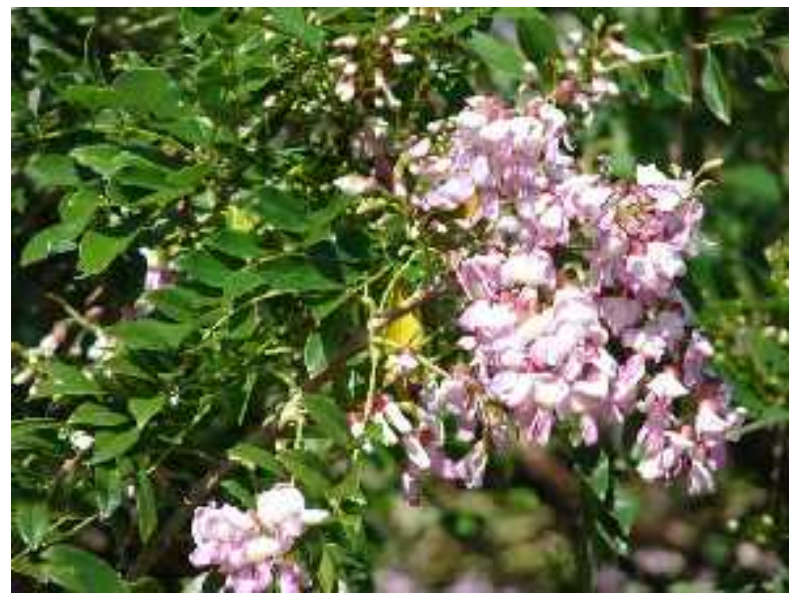

Gamal adalah tanaman multiguna yang paling banyak kedua dibudidayakan setelah lamtoro. Tanaman ini dapat digunakan untuk mereklamasi lahan yang gundul atau tanah yang ditumbuhi alang alang rapat. Konon, nama gamal merupakan akronim dari ganyang mati alang-alang. 


\section{Morfologi Gamal}

Pohon Gamal berukuran kecil sampai sedang tinggi sekitar 10-12 m. Daun bersirip ganjil, panjang sekitar $30 \mathrm{~cm}$. Helai daun 5-20 $\mathrm{cm}$, berbentuk oval sampai bulat, panjang 2-7 $\mathrm{cm}$, dan lebar 1-3 cm.

Bunga membentuk kelompok tangkai pada batang muda dan tua. Bunga keluar tunggal dengan 20-40 per tangkai, merah muda sampai ungu muda, bercampur putih.

Buah polong hijau dan kuning-cokelat muda ketika tua, panjang 0-18 cm, lebar $2 \mathrm{~cm}$, biji 4-10, kuning-cokelat muda sampai cokelat dan hampir bulat

\section{Klasifikasi ilmiah:}

$\begin{array}{ll}\text { Kingdom } & : \text { Plantae } \\ \text { Divisio } & : \text { Magnoliophyta } \\ \text { Classis } & : \text { Magnoliopsida } \\ \text { Ordo } & : \text { Fabales } \\ \text { Famili } & : \text { Fabaceae } \\ \text { Genus } & : \text { Gliricidia } \\ \text { Species } & : \text { Gliricidia maculata } \mathrm{Hbr} .\end{array}$

\section{Bidara (Ziziphus mauritiana)}

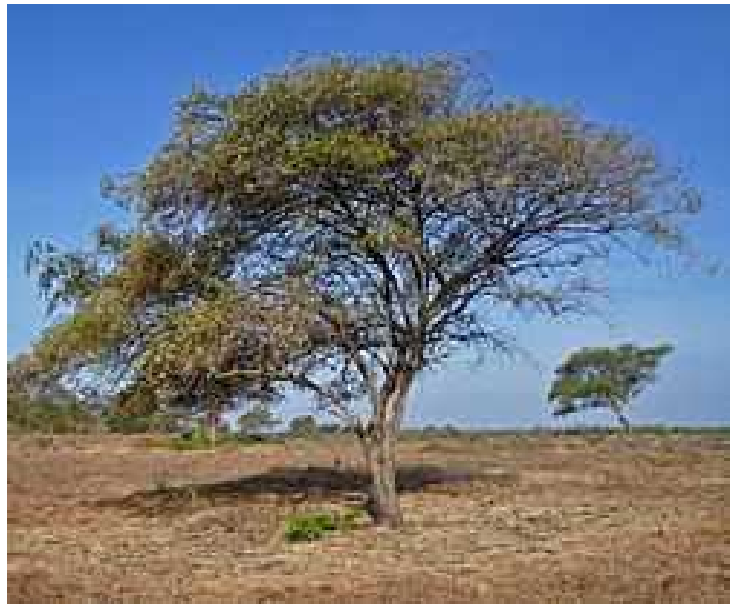

Tanaman bidara (Ziziphus) adalah pohon kecil yang selalu hijau dan banyak tumbuh di Indonesia, terutama di Sumbawa, Nusa Tenggara Barat. Tanaman bidara sebetulnya berasal dari Timur Tengah, namun telah menyebar ke berbagai wilayah tropis dan subtropics (Hutapea dan Syamsuhidayat, 1991)

\section{Ciri-cirinya:}

Pohon Bidara merupakan jenis tanaman perdu atau pohon kecil, biasanya bengkok, dan tingginya bisa mencapai $15 \mathrm{~m}$, sementara besar batangnya mencapai $40 \mathrm{~cm}$.
Pohon ini memiliki daun yang lebat dan berwarna hijau. Daunnya berbentuk pasangan dimorfis, yang mana yang kedua melengkung dan lebih pendek, terkadang tanpa duri. Daunnya juga tidak berseling. Helai daunnya berbentuk bundar telur menjorong atau jorong lonjong (Hutapea dan Syamsuhidayat, 1991).

\section{Klasifikasi ilmiah:}

$\begin{array}{ll}\text { Kerajaan } & : \text { Plantae } \\ \text { Divisi } & : \text { Magnoliophyta } \\ \text { Classis } & : \text { Magnoliopsida } \\ \text { Ordo } & : \text { Rosales } \\ \text { Famili } & : \text { Rhamnaceae } \\ \text { Genus } & : \text { Ziziphus } \\ \text { Spesies } & : \text { Z. mauritiana }\end{array}$

\section{Randu (Ceiba pentandra)}

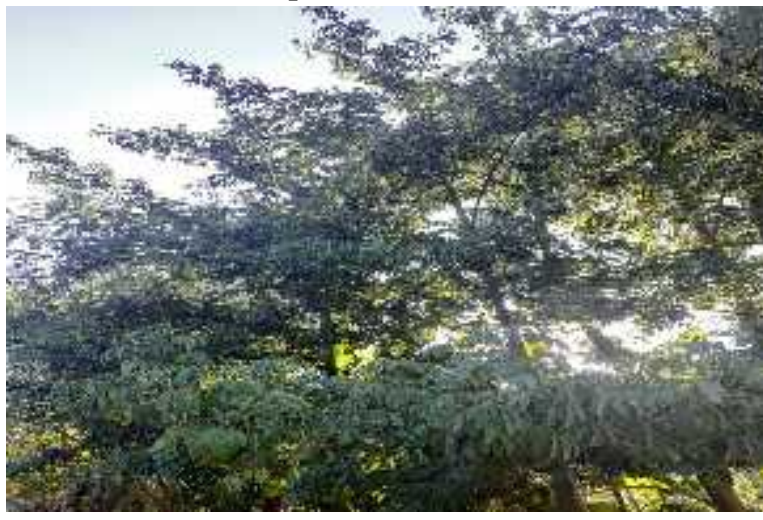

Kapuk

randu atau kapuk ( pentandra) adalah pohon tropis yang tergolong ordo Malvales dan famili Malvaceae (sebelum nya dikelompokkan ke dalam famili terpisah Bombacaceae). Tanaman ini berasal dari Amerika Selatan bagian utara, Amerika Tengah dan Karibia. Untuk varitas $C$. pentandra var. guineensis berasal dari sebelah barat Afrika (Hanan, 1996)

\section{Ciri-cirinya :}

Pohon ini bisa tumbuh hingga setinggi 60-70 m. Batang pohon dapat mencapai diameter 3 meter. Akar pohon kapuk menyebar secara hozontal di permukaan tanah. Batang dapat menjulang dengan atau tanpa cabang. Sering juga ditemui duri-duri di batang pohon kapuk.

Tanaman ini akan tumbuh dengan baik pada ketinggian $<500$ meter dan temperatur malam hari kurang dari 17 derajat 
Celcius. Tanaman ini menyukai curah hujan yang tinggi, sekitar 1500-2500 mm/tahun. Tanaman kapuk mudah rusak oleh angin yang kuat.

Buah kapuk yang sudah kering merupakan sumber serat, digunakan untuk bahan dasar matras, bantal, hiasan dinding, pakaian pelindung, dan penahan panas serta peredam suara. Kulit kering buah kapuk dapat digunakan sebagai bahan bakar. Bijinya yang mengandung minyak yang digunakan sebagai pelumas dan minyak lampu, oleh sebab itu dapat dipakai sebagai bahan baku energi (Hanan, 1996).

\section{Klasifikasi Ilmiah:}

$\begin{array}{ll}\text { Kerajaan } & : \text { Plantae } \\ \text { Divisi } & : \text { Magnoliophyta } \\ \text { Classis } & : \text { Magnoliopsida } \\ \text { Ordo } & : \text { Malvales } \\ \text { Famili } & : \text { Malvaceae } \\ \text { Genus } & : \text { Ceiba } \\ \text { Spesies } & : \text { C. pentandra }\end{array}$

\section{Jati Putih (Gmelina Arborea)}

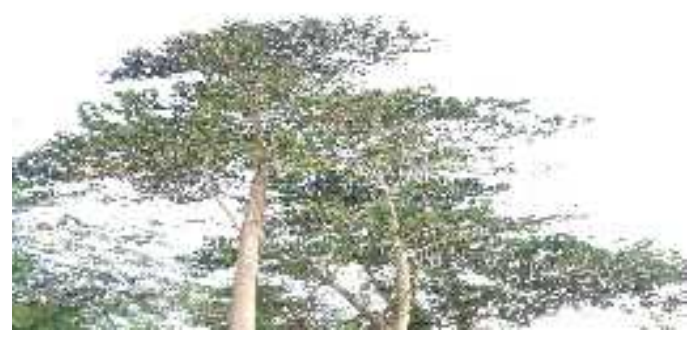

Jati Putih termasuk tanaman penghasil kayu yang produktif. Tanaman jati putih berasal dari Asia Tenggara, di negara lain dikenal dengan nama Gamari atan Gumadi (India), Gamar (Bangladesh) atau Yemane (Myanmar). Banyak ditanam sebagai tanaman pelindung, sebagian besar dimanfaatkan sebagai tanaman komersial. Sekarang (Januari 2009) tanaman ini banyak ditanam di daerah KabupatenBulukumba, Sulawesi Selatan, Indo nesia. Para petani tertarik dengan nilai kayu jenis ini. Semua bagian pohon dapat dimanfaatkan untuk dijual, mulai dari batang gelondongan, cabang bahkan ranting. Nilai ekonomis katu ini yang tinggi membuat tanaman ini ditanam dari tepi jalan, di kebun, di halaman dan sebagainya (Nasution, 1986).

\section{Ciri-cirinya:}

Buah : Berdaging, panjang 20-35 mm, kulit mengkilat, mesokarp lunak, agak manis. Biji : Keras seperti batu, panjang 16-25 mm, permukaan licin, satu ujung bulat, ujung lain runcing. Terdiri dari 4 ruang, jarang dijumpai 5 ruang. Sedikitnya satu ruang berisi benih, jarang dalam satu buah terdiri dari dua biji batu. Ukuran benih meningkat menurut ukuran biji, yaitu panjang $6-9 \mathrm{~mm}$. Berat 1.000 butir biji batu sekitar $400 \mathrm{gr}$.

\section{Klasifikasi Ilmiah:}

$\begin{array}{ll}\text { Kerajaan } & : \text { Plantae } \\ \text { Divisi } & : \text { Magnoliophyta } \\ \text { Classis } & : \text { Magnoliopsida } \\ \text { Ordo } & : \text { Lamiales } \\ \text { Famili } & : \text { Lamiaceae } \\ \text { Genus } & : \text { Gmelina } \\ \text { Spesies } & \text { Gmelina arborea Roxb }\end{array}$

10. Mahoni (Swietenia Mahagoni)

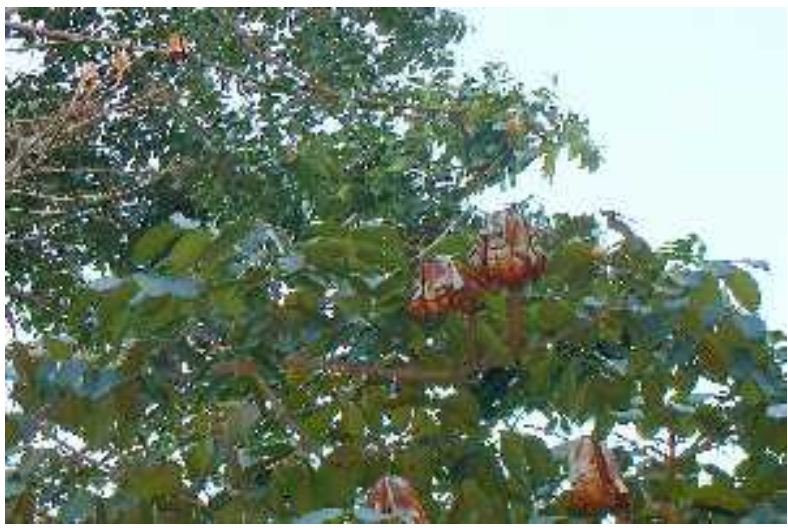

Mahoni adalah anggota suku Meliaceae yang mencakup 50 genera dan 550 spesies tanaman kayu (Daliniartha, 2003)

\section{Ciri-cirinya:}

Menurut Daliniartha (2003) dalam bukunya cirri-ciri pohon mahoni sebagai berikut:

1. Mahoni termasuk pohon besar dengan tinggi pohon mencapai $35-40 \mathrm{~m}$ dan diameter mencapai $125 \mathrm{~cm}$.

2. Batang lurus berbentuk silindris dan tidak berbanir.

3. Kulit luar berwarna cokelat kehitaman, beralur dangkal seperti sisik, sedangkan kulit batang berwarna abu-abu dan halus ketika masih muda, berubah menjadi cokelat tua, beralur dan mengelupas setelah tua. 
4. Mahoni baru berbunga setelah berumur 7 tahun, mahkota bunganya silindris, kuning kecoklatan, benang sari melekat pada mahkota, kepala sari putih, kuning kecoklatan.

5. Buahnya buah kotak, bulat telur, berlekuk lima, warnanya cokelat. Biji pipih, warnanya hitam atau cokelat

\section{Klasifikasi Ilmiah}

$\begin{array}{ll}\text { Kerajaan } & \text { : Plantae } \\ \text { Divisi } & : \text { Rosidae } \\ \text { Classis } & : \text { Magnoliopsida } \\ \text { Ordo } & : \text { Sapindales } \\ \text { Famili } & : \text { Meliaceae } \\ \text { Genus } & : \text { Swietenia } \\ \text { Spesies } & : \text { S. macrophylla }\end{array}$

\section{Kayu Jawa (Lannea cormandelica)}

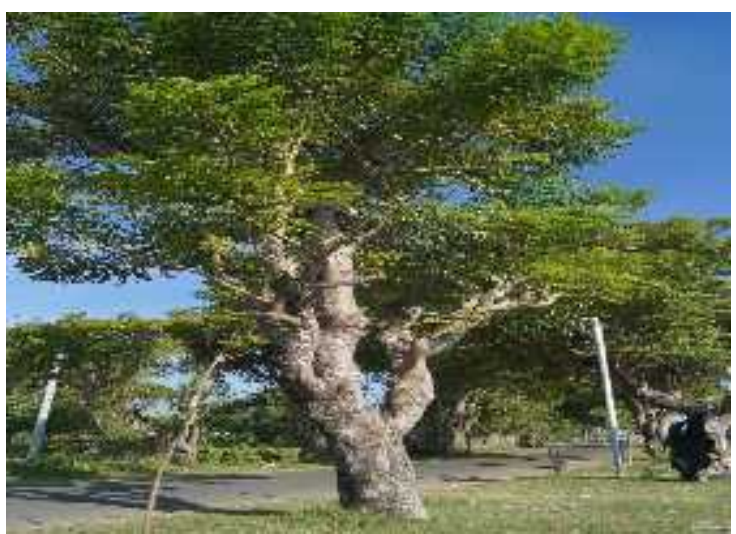

Lannea coromandelica, juga dikenal sebagai pohon kuda kuda atau pohon jawa adalah spesies pohon dalam keluarga Anacardiaceae yang tumbuh di Asia Selatan dan Asia Tenggara (Surwono, 2001)

\section{Ciri-cirinya:}

Lannea coromandelica adalah tumbuhan liar yang berwarna hijau,permukaan daun licin, bentuk majemuk menyirip gasal, anak daun berhadapan, tulang daun menyirip; diameter daun 4,4 - 5,0 cm; panjang daun 7,3 $10,5 \mathrm{~cm}$;panjang tangkai daun $0,3-0,8 \mathrm{~cm}$, bentuk daun bulat telur, dan ujung daun runcing (Surwono, 2001).

$\begin{array}{ll}\text { Divisi } & : \text { Tracheophyta } \\ \text { Classis } & : \text { Dicotyledonane } \\ \text { Ordo } & : \text { Sapindales } \\ \text { Famili } & : \text { Anacardiaceae } \\ \text { Genus } & : \text { Lannea } \\ \text { Spesies } & : \text { L. coromandelica }\end{array}$

Jenis Pohon Tumbuhan Bawah

1. Kopasanda (Chromolaena odorata)

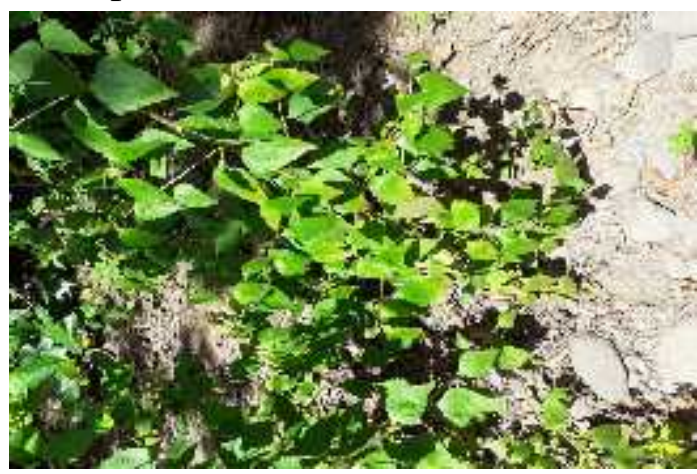

Tanaman Kopasanda termasuk tanaman yang umum ditemui karena tanaman ini merupakan jenis tanaman liar. Walau merupakan tumbuhan liar, sebenarnya tanaman ini hampir ada di setiap daerah terutama pada tempat-tempat yang ditumbuhi rumput liar. Tumbuhan kopasanda tersebut tumbuh tegak dengan tinggi antara 1 sampai $2 \mathrm{~m}$, batang tegak, berkayu, ditumbuhi rambut rambut halus, bercorak garis-garis membujur yang paralel (Nasution,1986).

Tanaman Kopasanda termasuk salah satu gulma yang awalnya diketahui berasal dari Amerika Selatan dan Tengah, setelah itu tanaman tersbut kemudian menyebar ke daerah tropis Asia, Afrika, Pasifik, dan menyebar dinegara kita ini Indonesia.Daun kopasanda atau daun golkar berbentuk oval, dimana bagian bawahnya lebih lebar dan semakin ke ujung semakin meruncing. Panjang daun tersebut antara 6 hingg $10 \mathrm{~cm}$ dan lebar daunnya 3 hingga 6 $\mathrm{cm}$. Tepi daun bergerigi dan susunan daun berhadap hadapan (Chakraborty,dkk,2010).
Klasifikasi Ilmiah:

Kerajaan

: Plantae

\section{Klasifikasi ilmiah:}

Kingdom : Plantae 


$\begin{array}{lll}\text { Divisi } & : & \text { Spermatophyta } \\ \text { Classis } & : & \text { Dicotyledonae } \\ \text { Ordo } & : & \text { Asterales } \\ \text { Famili } & : & \text { Asteraceae } \\ \text { Genus } & : & \text { Chromolaena } \\ \text { Spesies } & : & \text { C. odorata }(\text { L. })\end{array}$

\section{Pacar Kuku (Lawsonia inermis)}

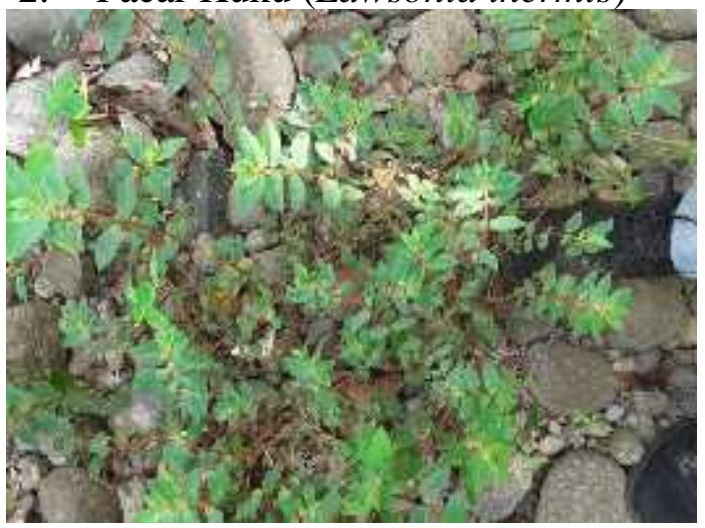

Tanaman yang berasal dari Afrika Timur Laut dan Asia Barat Daya.Termasuk suku Lythaceae.

\section{Ciri-ciri:}

Batangnya perdu, tegak, cabangcabangnya sering berujung runcing. Daun berhadapan, berbentuk jorong atau jorong-lanset, panjang $1,5-5,0 \mathrm{~cm}$. Perbungaan berupa malai, tumbuh di ujung cabang dan di ketiak daun, panjang $4-20 \mathrm{~cm}$, bunga kuning muda, merah jambu, atau merah, sangat harum. Sementara buahnya berupa buah kotak, berbentuk bulat, atau bulat pipih, dan memiliki garis tengah $\pm 0,5 \mathrm{~cm}$

\section{Kegunaan}

Pacar kuku banyak ditanam sebagai tanaman hias, karena bunganya berbunga sepanjang tahun, maka seringpula digunakan dalam wangi-wangian. Pacar kuku di Indonesia juga paling dikenal sebagai pemerah kuku tradisional dengan cara menumbuk daun dengan kapur atau gambir untuk mewarnai merah kuku. Tidak hanya itu, dalam bentuk kering, apabila daunnya ditumbuk dengan air, maka dapat digunakan untuk mewarnai rambut katilalo" (Jatropha curcas L.)

Daun pacar kuku mengandung zat warna yang dapat diekstrak sebagai kristal berwarna kuning jingga, digunakan untuk mewarnai wol dan sutera. Daun mengandung tanin $( \pm 4,5 \%)$, digunakan untuk obat penghenti diare ; serbuk daun digunakan untuk obat luka. Bunga mengandung minyak atsiri yang berbau seperti trimetil amina, digunakan dalam kosmetika. Biji mengandung minyak (10,5\%). Kayu kelabu, keras, digunakan untuk membuat barang-barang kecil dan tusuk gigikatilalo" (Jatropha curcas L.).

\section{Klasifikasi ilmiah:}

$\begin{array}{lll}\text { Kingdom } & : & \text { Plantae } \\ \text { Divisi } & : & \text { Magnoliophyta } \\ \text { Classis } & : & \text { Magnoliopsida } \\ \text { Ordo } & : & \text { Myrtales } \\ \text { Famili } & : & \text { Lytthracea } \\ \text { Genus } & : & \text { Lawsonia } \\ \text { Spesies } & : & \text { Lawsonia inermis }(L .)\end{array}$

\section{KESIMPULAN}

Berdasarkan hasil penelitian dan analisis yang telah dilakukan, maka dapat disimpulkan sebagai berikut :

Identifikasi jenis Vegetasi yang di jumpai pada Lokasi Hutan Lindung Kesatuan Pengelolaan hutan(KPHL) Ampang ditemukan sebanyak 27 jenis vegetasi terdiri dari 11 Jenis adalag pada tingkat tian dan 16 jenis pada tingkat tumbuhan bawah, yang termasuk jenis pakan lebah madu hutan (Apisdorsata).

\section{SARAN}

1. Di harapkan dari hasil penelitian ini ada upaya tindak lanjut dari pemerintah perlu upaya pelestarian jenis tanaman sebagai jenis pakan lebah madu hutan khususnya di Kawasan Hutan Kesatuan Pengelolaan Hutan Lindung (KPHL) Ampang

2. Perlu adanya penelitian lebih lanjut dalam Kegiatan Inventarisasi tentang Analisa Vegetasi dalam Kawasan Hutan yang dapat digunakan sebagai pembanding hasil penelitian yang sudah dilakukan.

\section{DAFTAR PUSTAKA}

Fachrul., 2007. Metode Sampling Bioekologi. Bumi Aksara, Jakarta.

Free JB. 1982. Bees and Mankind. Oxford London and Norhampton Alden Press.

Husch.1987.PerencanaanInventarisasiHutan(dit erjemahkanolehAgusSetyarso).PenerbitUniversit as Indonesia. Jakarta.

Morse, R. A., and T. Hooper. 1985.The Illustrated Encyclopedia of Beekeeping. BlanfordPress,England. 
Oertel E. 1980. Nectar and Pollen Plants in Beekeeping in the United States.Washington: United States Department of Agriculture.

Stelly DG. 1983. Beekeeping an illustrated Handbook. Amerika:Tab Book Inc.

Soerianegara, I dan A. Indrawan. 1988. EkologiHutan Indonesia. Departemen ManajemenHutanFakultasKehutanan IPB, Bogor.

Sumoprastowo, R.M. danSuprapto, R.A. 1980. Beternak Lebah Madu Modern. BhrataraKaryaAksara. Jakarta. $217 \mathrm{hlm}$.

Warisno. $1996 . \quad$ BudidayaLebahMadu.

Yokjakarta. Kanisius. 